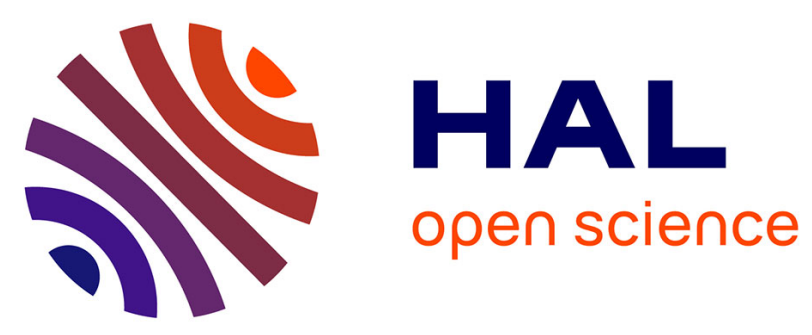

\title{
Sexual maturity in sea trout, Salmo trutta L., running up the river Calonne (Normandy, France) at the "finnock" stage
}

Gérard Maisse, Brigitte Mourot, Bernard Breton, Alexis Fostier, Odile Marcuzzi, Pierre-Yves Le Bail, Jean-Luc J.-L. Baglinière, A. Richard

\section{To cite this version:}

Gérard Maisse, Brigitte Mourot, Bernard Breton, Alexis Fostier, Odile Marcuzzi, et al.. Sexual maturity in sea trout, Salmo trutta L., running up the river Calonne (Normandy, France) at the "finnock" stage. Journal of Fish Biology, 1991, 39, pp.705-715. 10.1111/j.1095-8649.1991.tb04400.x . hal-02715200

\section{HAL Id: hal-02715200 \\ https://hal.inrae.fr/hal-02715200}

Submitted on 1 Jun 2020

HAL is a multi-disciplinary open access archive for the deposit and dissemination of scientific research documents, whether they are published or not. The documents may come from teaching and research institutions in France or abroad, or from public or private research centers.
L'archive ouverte pluridisciplinaire HAL, est destinée au dépôt et à la diffusion de documents scientifiques de niveau recherche, publiés ou non, émanant des établissements d'enseignement et de recherche français ou étrangers, des laboratoires publics ou privés. 


\title{
Sexual maturity in sea trout, Salmo trutta L., running up the River Calonne (Normandy, France) at the 'finnock' stage
}

\author{
G. Maisse, B. Mourot, B. Breton, A. Fostier, O. Marcuzzi, P. Y. Le Bail, \\ J. L. BAGLINIERE AND A. RICHARD* \\ I.N.R.A., Station de Physiologie et d'Ecologie des Poissons, 35042 Rennes Cedex and \\ *Conseil Supérieur de la Pêche, Délégation Régionale No. 2, 84 rue de Rennes, 35510 \\ Cesson Sévigné, France
}

(Received 7 March 1991, Accepted 1 June 1991)

\begin{abstract}
Sexual maturation in sea trout (Salmo trutta L.) running up the River Calonne (Normandy, France), at the finnock stage, is characterized. Autopsy of 118 finnock in summer showed that $87 \pm 7 \%$ aged $2+$ and $33 \pm 15 \%$ aged $1+$ were undergoing gametogenesis. In autumn all the fish were maturing. The analysis of plasma levels of 11 -ketotestosterone, 17 $\beta$-oestradiol, maturational gonadotropin and vitellogenin showed that only females in vitellogenesis can be well identified in summer (plasma vitellogenin greater than $0.30 \mathrm{mg} \mathrm{m}^{-1}$ ). The morphological recognition of females among 134 autumn finnock and the ELISA assay of plasma vitellogenin of 814 summer finnock, demonstrated that vitellogenic females represented $12 \pm 2 \%$ of the $1+$ individuals and $46 \pm 2 \%$ of $2+$ fish captured during the 1985 run. The question of a possible relationship between the salinity tolerance of juvenile trout migrating towards the sea in the spring and their age on first migration in the river is discussed.
\end{abstract}

Key words: Salmo trutta; finnock; maturity; vitellogenin; ELISA.

\section{INTRODUCTION}

Sea trout (Salmo trutta L.), which run up river the same year as their first migration into the sea, are called ' finnock' (or ' whitling ' in the U.K.). Finnock constitute a very variable part of the migrating population, both between years and rivers: 1 83\% in Ireland (Went, 1962), 47-72\% in the North Esk River in Scotland (Pratten \& Shearer, 1983), 1-30\% in Normandy, France (Fournel \& Euzenat, 1979; Richard, 1982, 1986). The proportion of spawning finnock is variable, depending on the river (Le Cren, 1985). O'Farrell (cited by Le Cren, 1985), using the gonadosomatic index, showed that $8 \%$ of female and $13 \%$ of male finnock were mature at the end of summer in the River Erriff (Ireland). Fahy (1978), in a review of the biological characteristics of sea trout in the British Isles, reported that the percentage of mature finnock was greater, on average, in Wales $(30.95 \%)$ than in Scotland $(6 \cdot 15 \%)$ or in Ireland $(8 \cdot 76 \%)$. In France, Richard (1986) analysed scales from the oldest trout, and estimated the proportion of finnock which spawned at $25 \%$ for $2+$ and $1 \%$ for $1+$. However, these latter numbers, which rely on the recognition of spawning marks, are probably underestimates, due to the higher mortality rate among spawners than among immature fish, and to the fact that the spawning marks are not always present. This phenomenon has already been observed in salmonids by numerous authors and in particular by O'Farrell (cited by Le Cren, 1985 ) who noted that only $28 \%$ of female and $22 \%$ of male finnock, which have previously spawned, had spawning marks on their scales. 
To understand further what determines the migratory behaviour of finnock, we recorded their sex and state of maturity. We measured plasma levels of sex hormones (11-ketotestosterone, 17 $\beta$-oestradiol) and of vitellogenin, which, according to Le Bail \& Fostier (1984), are the most discriminating factors at the beginning of gametogenesis for recognizing sexes in salmonids. We studied the sea trout in the River Calonne (Normandy) which had already been described by Richard (1986). These finnock are characterized by (1) their abundance ( $22 \%$ of the catch in 1984); (2) their upstream migration period (beginning of July to the end of December); (3) their age at first downstream migration (most at 2 years), the majority of sea trout moving upstream after at least one sea winter having smoltified at 1 year; (4) their large size when running upstream ( $25-44 \mathrm{~cm}$ F.L.), being one of the fastest growing trout populations at this stage; and (5) a balanced sex ratio.

\section{MATERIALS AND METHODS}

\section{THE FISH}

Sea trout were trapped continuously from July-December 1985, at Pont L'Evêque, $20 \mathrm{~km}$ from the sea, on the River Calonne, the principal tributary $(46.1 \mathrm{~km})$ of the lower part of the River Touques $\left(109 \mathrm{~km}, 1350 \mathrm{~km}^{2}\right)$. The trap approached $100 \%$ efficiency (Richard, 1986). Finnock were identified and their migration age determined by scalimetry, according to the interpretation proposed by Richard and Baglinière (1990). All fish were measured for fork length, and sexed in autumn by external morphology-principally head shape (Richard, 1986). They were also examined for the presence of sea lice (Lepeophtheirius salmonis) to indicate how recently they had left salt water.

\section{SAMPLING}

Fish were sampled every 2 weeks in summer (July and August) and monthly in autumn (October, November and December). They were killed under anaesthesia and the gonads and eviscerated carcass were weighed to determine the gonadosomatic index (GSI). The diameters of 40 opaque oocytes per female were measured (showing the incorporation of vitellin reserves). The GSI and the oocyte diameter were analysed by comparison with Billard's (1987) results for brown trout (Salmo trutta L.). The weight of both gonads was recorded in the male, to assess the state of maturing in summer, when the GSI approaches zero (males were considered in spermatogenesis when testes attained or were greater than a total weight of $0.2 \mathrm{~g}$ ).

\section{ASSAY}

Two $\mathrm{ml}$ of blood was sampled from each fish, for analysis of plasma 11-ketotestosterone (11-KT), 17 $\beta$-oestradiol (E2) and maturational gonadotropin (GtH II, Kawauchi et al., 1989), using radioimmunoassays described by Le Bail et al. (1983), Fostier et al. (1978) and Breton et al. (1978).

An immuno-enzymatic assay (ELISA) was adapted to assay vitellogenin (VTG). VTG synthesis was induced in domestic male brown trout by a 15 days treatment (implant) of $5 \mathrm{mg} 17 \beta$-oestradiol $\mathrm{kg}^{-1}$ of fish. The blood was collected, centrifuged and the plasma stored at $-20^{\circ} \mathrm{C}$ until use. VTG was purified according to Tyler \& Sumpter (1990). Purified VTG was injected over a period of 4 months (eight injections of $100 \mu \mathrm{g}$ ) into rabbits. The antiserum, obtained from rabbit blood, was stored at $-20^{\circ} \mathrm{C}$ until use. For the assay, a microtitration plate (Greiner wells, flat bottom) was used. VTG (15 ng) was incubated in each well for $3 \mathrm{~h}$ at $37^{\circ} \mathrm{C}$ in sodium bicarbonate buffer (50 mM, pH 9.6) containing $5 \mathrm{mg} \mathrm{l}^{-1}$ gentamycin, for coating. Coating was followed by washing with buffer which contained tris- $\mathrm{HCl} 10 \mathrm{~mm}, \mathrm{pH} 7.5, \mathrm{NaCl} 0.15 \mathrm{M}$, Tween $0.1 \%$ and gentamycin $5 \mathrm{mg}$ $1^{-1}$ (TBS-T). This was repeated after each incubation. Then, the aspecific sites of the plate were saturated with $2 \%$ pig serum in TBS-T-SP for $30 \mathrm{~min}$. Specific antibody $(75 \mathrm{ml})$ was diluted in TBS-T-SP buffer (1:60000 dilution) and incubated with $75 \mu$ lof sample for $16 \mathrm{~h}$ 
at $20^{\circ} \mathrm{C}$. The incubation with the second antibody $(150 \mu \mathrm{l}$ of sheep serum anti rabbit gamma-globulins diluted to $1: 4000$ in TBS-T-SP) was conducted for $2 \mathrm{~h}$ at $37^{\circ} \mathrm{C}$. Incubation with the pork peroxidase anti-peroxidase (Dako code Z113), diluted to 1:5000 in TBS-T-SP, was conducted for $1 \mathrm{~h}$ at $37^{\circ} \mathrm{C}$.

One hour after the addition of $150 \mu \mathrm{l}$ of a solution of $0.5 \mathrm{~g} \mathrm{l}^{-1} \mathrm{O}$-phenylene diamine, $0.5 \mathrm{ml}^{-1}$ of $30 \%$ hydrogen peroxide in an ammonium acetate-citric acid (50 mM, pH 5) buffer, the reaction was stopped by the addition of $50 \mu \mathrm{l} 5 \mathrm{~m}$ sulphuric acid. The optical density was measured with a Microplate autoreader (EL311 Biotech instrument), using double wavelength $(490$ and $90 \mathrm{~nm})$, the readings being compared with those of known quantities of purified VTG. Non-specific binding was determined by reading the absorbance of four wells per plate containing VTG but without specific antibody.

\section{STATISTICAL ANALYSIS}

As the different plasma parameters were not normally distributed, they were analysed by factorial analysis of correspondences (Benzecri, 1973) applied to a contingency table with modalities of plasma parameters according to sexual stages defined from biometric parameters. For the validation of the enzymoimmunoassay the variables were transformed as follows:

$$
X=\log (x) ; Y=\log \left\{\left(B / B_{0}\right) /\left(1-B / B_{0}\right)\right\}
$$

where $x$ is the quantity of VTG in the sample, $B$ the optical density reading for the wells, and $B_{0}$ the reading in the absence of VTG. The parallelism between regression lines $Y=f(X)$ was tested using the analysis of covariance.

\section{RESULTS}

\section{VALIDATION OF ELISA ASSAY FOR VITELLOGENIN}

The value of non-specific binding was always less than $2 \cdot 5 \%$. The sensitivity limit of the assay was $3 \cdot 4 \pm 0 \cdot 1 \mathrm{ng}$ per well $(n=6)$. At $50 \%$ binding this value was $31 \cdot 1 \% \pm 2 \cdot 4 \mathrm{ng}$ per well $(n=6)$. The inter-assay and intra-assay coefficients of variation obtained at $50 \%$ binding were $14.5 \%(n=4)$ and $7 \cdot 8 \%(n=6)$ respectively. The specificity of the assay was tested for the sera of different salmonid species (Fig. 1). Only the inhibition curve for the oestrogen-treated brown trout was parallel to that of the standard obtained using dilutions of purified brown trout VTG. In the case of the other salmonids (rainbow trout, Oncorhynchus mykiss Walbaum, Atlantic salmon, Salmo salar L., chinook salmon, Oncorhynchus tshawytscha Walbaum, and brook trout Salvelinus fontinalis Mitchill) the curves were sigmoid, indicating partial recognition of the VTG of these fish by antibody families having different affinities for the molecule. The assay is, thus, specific to brown trout VTG. The serum of male brown trout shows that there is a serum effect for dilutions less than $1: 50$. In this serum there was not a large amount of inhibition.

\section{FINNOCK CHARACTERISTICS}

Of the 1189 finnock captured between July and December $89 \%$ were caught in summer ( $76 \%$ in July). Of these, $78 \%$ had migrated to sea at age $2+$ and $<1 \%$ at $3+($ Table I).

Of the 159 fish sampled throughout the study, all 40 in autumn were mature (GSI $>5 \%$ in females and $>1 \%$ in males, Fig. 2 ).

In summer the maturity rate was greater in $2+(87 \pm 7 \%)$ than in the $1+$ fish $(33 \pm 15 \%)$. Vitellogenic females were better represented in the first age group 

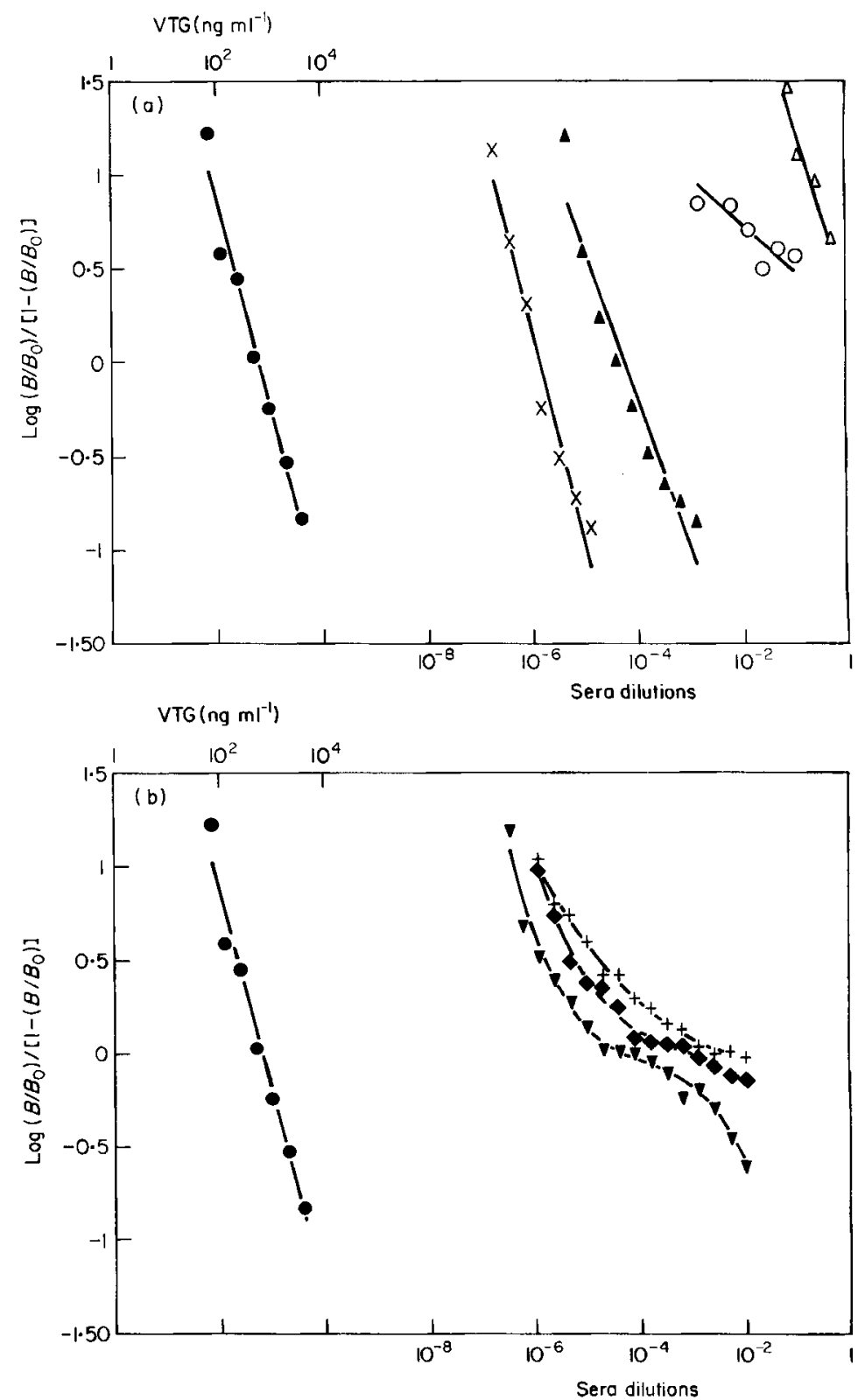

F1G. 1. Validation of ELISA for vitellogenin inhibition curves for (a) oestradiol-treated brown trout $(x)$, oestradiol-treated Atlantic salmon $(\Delta)$, male brown trout $(O)$ and ram sera $(\triangle)$ and (b) rainbow trout $(\nabla)$, chinook salmon $(\bullet)$, and brook trout sera $(+)$, compared with that of the standard obtained using dilutions of purified brown trout VTG $(\bullet)$.

$(49 \pm 11 \%)$ than in the second $(8 \pm 8 \%)$ (Table II). The sex ratio was balanced and did not differ significantly between $1+$ and $2+$. The majority of summer finnock carried sea lice or scars whereas all autumn fish were unscathed (Table III). 
TABLE I. Length characteristics of finnock captured in the trap of the River Calonne, by age and season

\begin{tabular}{|c|c|c|c|c|}
\hline \multirow[b]{2}{*}{ Age } & \multicolumn{2}{|c|}{ Summer } & \multicolumn{2}{|c|}{ Autumn } \\
\hline & No. & $\begin{array}{c}\text { Fork length } \\
\text { (mm) } \\
\text { [range] }\end{array}$ & No. & $\begin{array}{c}\text { Fork length } \\
\text { (mm) } \\
\text { [range] }\end{array}$ \\
\hline $1+$ & 243 & $\begin{array}{c}294 \\
{[255-354]}\end{array}$ & 14 & $\begin{array}{c}337 \\
{[303-430]}\end{array}$ \\
\hline $2+$ & 807 & $\begin{array}{c}344 \\
{[263-444]}\end{array}$ & 119 & $\begin{array}{c}369 \\
{[309-450]}\end{array}$ \\
\hline $3+$ & 6 & $\begin{array}{c}354 \\
{[334-367]}\end{array}$ & 0 & \\
\hline
\end{tabular}

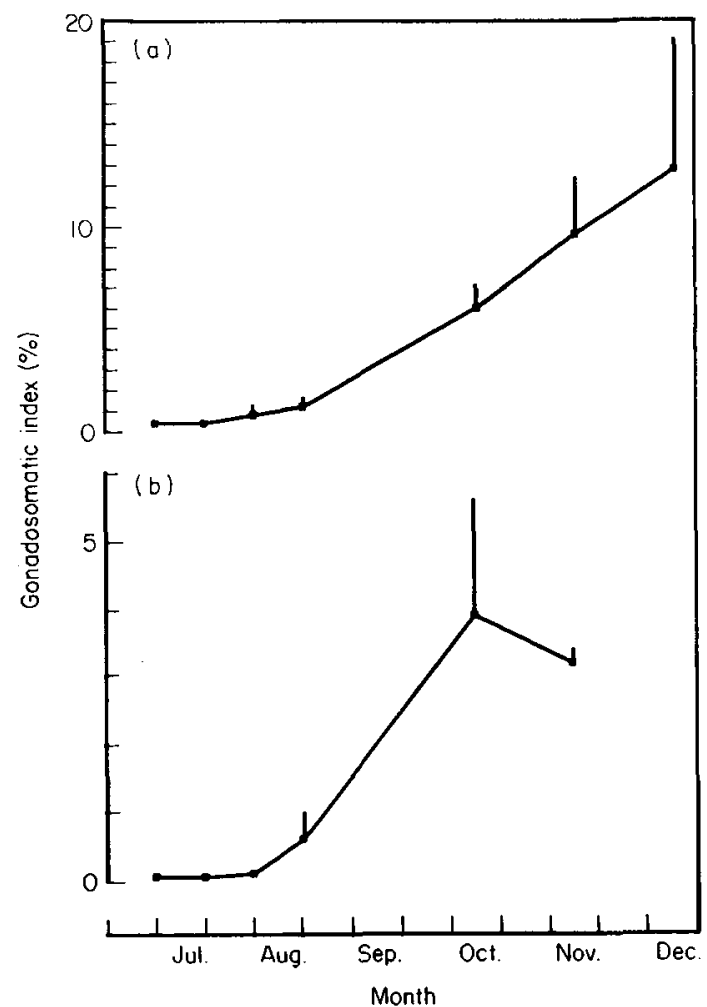

FIG. 2. Gonadosomatic index of (a) female and (b) male finnock captured in the trap on the River Calonne. Mean +S.D.

From 118 of the summer samples, blood parameter values varied widely, and none were normally distributed (Table IV). Plasma VTG characterized vitellogenic females, with values always greater than $0.45 \mathrm{mg} \mathrm{m}^{-1}$ for all other finnock plasma VTG levels were less than $0.06 \mathrm{mg} \mathrm{ml}^{-1}$. 
TABLE II. Distribution (in \%) by age, sex and maturity stage (noted after gonad examination), of fish sampled during summer from the trap on the River Calonne

\begin{tabular}{lcccc}
\hline Age & $\begin{array}{c}\text { Spermatogenic } \\
\text { males }\end{array}$ & $\begin{array}{c}\text { Vitellogenic } \\
\text { females }\end{array}$ & $\begin{array}{c}\text { Immature } \\
\text { males }\end{array}$ & $\begin{array}{c}\text { Immature } \\
\text { females }\end{array}$ \\
\hline $\begin{array}{l}1+ \\
(n=36)\end{array}$ & 25 & 8 & 34 & 33 \\
$\begin{array}{l}2+ \\
(n=83)\end{array}$ & 37 & 49 & 4 & 10 \\
\hline
\end{tabular}

TABLE III. Occurrence of sea lice and scars (in $\%)$ in $1+$ and $2+$ finnock captured in the trap on the River Calonne

\begin{tabular}{lrrrrr}
\hline & \multicolumn{2}{c}{$1+$ Finnock } & & \multicolumn{2}{c}{$2+$ Finnock } \\
\cline { 2 - 3 } \cline { 5 - 6 } & \multicolumn{2}{c}{ Summer Autumn } & Summer Autumn \\
\hline Sea lice & 57.5 & 0 & 48.9 & 0 \\
Scars & $9 \cdot 0$ & 0 & $11 \cdot 7$ & 0 \\
Unscathed & 33.5 & 100 & 39.4 & 100 \\
\hline
\end{tabular}

TABLE IV. Plasma vitellogenin and hormone levels of finnock captured during summer in the trap of the River Calonne, by sex and maturity stage

\begin{tabular}{|c|c|c|c|c|c|}
\hline & & $\begin{array}{c}\text { Spermatogenic } \\
\text { males } \\
(n=40)\end{array}$ & $\begin{array}{l}\text { Vitellogenic } \\
\text { females } \\
(n=44)\end{array}$ & $\begin{array}{c}\text { Immature } \\
\text { males } \\
(n=15)\end{array}$ & $\begin{array}{l}\text { Immature } \\
\text { females } \\
(n=19)\end{array}$ \\
\hline \multirow{4}{*}{$\begin{array}{l}\text { Vitellogenin } \\
\left(\text { mg ml }{ }^{\cdots 1}\right) \\
11-K_{\text {Ketotestosterone }} \\
\left(\text { ng ml }^{-1}\right)\end{array}$} & Mean & 0.005 & $20 \cdot 195$ & 0.002 & 0.006 \\
\hline & Range & $0.00-0.04$ & $0.45-107 \cdot 80$ & $0.00-0.01$ & $0.00-0.06$ \\
\hline & Mean & 0.656 & 0.147 & 0.375 & 0.172 \\
\hline & Range & $0.14-1.43$ & $0.10-0.36$ & $0 \cdot 10-1 \cdot 25$ & $0.10-0.67$ \\
\hline \multirow{2}{*}{$\begin{array}{l}\text { 17ק-Oestradiol } \\
\left(\mathrm{ng} \mathrm{ml}^{-1}\right)\end{array}$} & Mean & 0.730 & 0.610 & 0.517 & 0.769 \\
\hline & Range & $0.11-3.09$ & $0 \cdot 10-1.98$ & $0.05-1.81$ & $0 \cdot 22-1 \cdot 52$ \\
\hline \multirow{2}{*}{$\begin{array}{l}\text { Gonadotropin } \\
\left(\mathrm{ng} \mathrm{ml}^{-1}\right)\end{array}$} & Mean & 3.082 & $4 \cdot 180$ & $6 \cdot 740$ & 4.964 \\
\hline & Range & $0.86-9.05$ & $0 \cdot 26-18.95$ & $0.88-18 \cdot 54$ & $1 \cdot 30-22 \cdot 85$ \\
\hline
\end{tabular}

The relationships of blood parameters to sex and maturity of the finnock were examined after drawing up a contingency table (Table V). Factorial analysis of correspondences with respect to factorial axis 1 and 2 (Fig. 3) shows that: (1) 


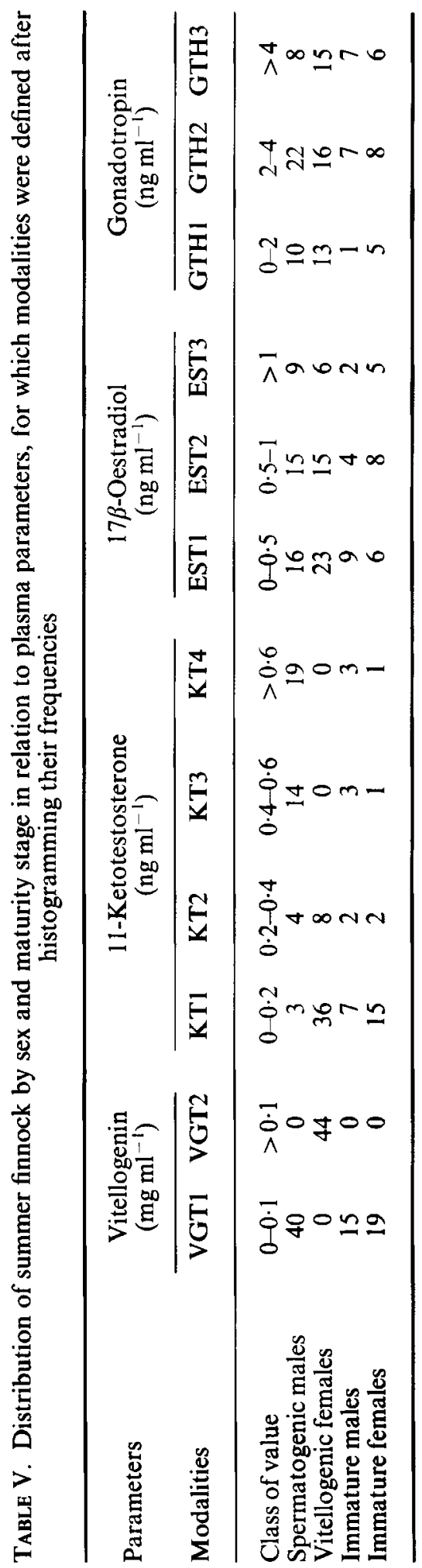




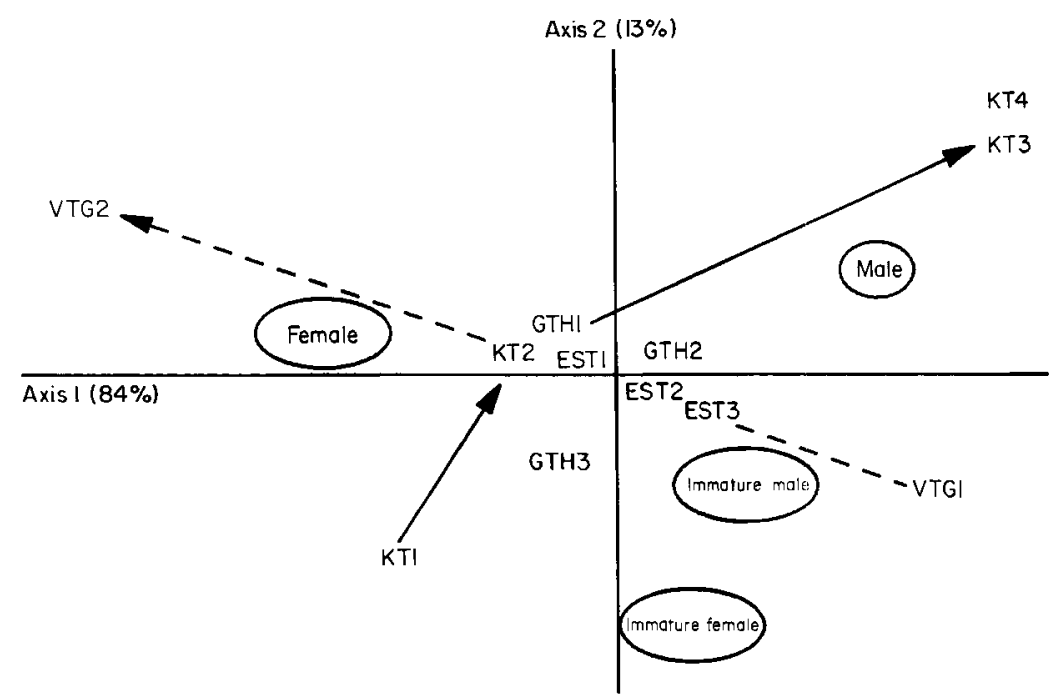

FIG. 3. Relationship between blood parameters, vitellogenin (VTG1, VTG2), gonadotropin (GTH1, GTH2, GTH3), 17 $\beta$-oestradiol (EST1, EST2, EST3), 11-ketotestosterone (KT1, KT2, KT3, KT4), and sex and the stage of maturity of the finnock after factorial analysis of Correspondences of the contingency Table IV.

TABLE VI. Estimated number and percentage of vitellogenic females (characterized in summer by plasma vitellogenin levels and in autumn by the dimorphism of head shape) in finnock captured in the trap on the River Calonne in 1985 ( \pm confidence limits at $5 \%$ )

\begin{tabular}{|c|c|c|c|c|c|c|}
\hline \multirow{2}{*}{ Age } & \multicolumn{2}{|c|}{ Summer } & \multicolumn{2}{|c|}{ Autumn } & \multicolumn{2}{|c|}{ Total } \\
\hline & $n$ & $\%$ & $n$ & $\%$ & $n$ & $\%$ \\
\hline $\begin{array}{l}1+ \\
2+\end{array}$ & $\begin{array}{r}24 \pm 5 \\
374 \pm 16\end{array}$ & $\begin{array}{l}10 \pm 2 \\
46 \pm 2\end{array}$ & $\begin{array}{r}6 \\
55\end{array}$ & $\begin{array}{l}43 \\
46\end{array}$ & $\begin{array}{r}30 \pm 5 \\
429 \pm 16\end{array}$ & $\begin{array}{l}12 \pm 2 \\
46 \pm 2\end{array}$ \\
\hline
\end{tabular}

vitellogenic females are distinguished from other categories by their high level of vitellogenin; (2) males in spermatogenesis are associated with higher levels of 11$\mathrm{KT}$; and (3) E2 and GtH II, whose modalities are grouped at the centre of the plan, have little discriminatory value. On the basis of these results, the VTG assay was also carried out on plasma from $6332+$ and $1811+$ finnock captured in summer (the plasma was diluted so as to be in the zone of maximum sensitivity of the standard range, 0.03 to $0.30 \mathrm{mg} \mathrm{ml}^{-1}$ ). Since only $0.5 \%$ had levels in this zone, we retained the value of $0.30 \mathrm{mg} \mathrm{ml}^{-1}$ as a minimum threshold for identification of females in vitellogenesis. In autumn the females were easily identifiable by their general morphology. The data in Table VI confirm $\left(\chi^{2} P<0.001\right)$ those established from the samples; females in vitellogenesis represented $12 \pm 2 \%$ of $1+$ and $46 \pm 2 \%$ of $2+$ finnock frequenting the River Calonne in 1985. 


\section{DISCUSSION}

\section{VALIDATION OF THE ELISA ASSAY FOR VITELLOGENIN}

The ELISA assay for VTG in the brown trout was sensitive enough to detect a minimum value of $3.4 \mathrm{ng}$ per well. Only the inhibition curve obtained from oestrogen-treated brown trout serum was parallel to that of the standard curve. Oestrogen-treated Atlantic salmon serum had very similar characteristics, unlike those from salmonids of the genera Salvelinus and Oncorhynchus, which suggests that the specificity of the assay is limited to the genus Salmo. Similar observations were made by Norberg \& Haux (1988) when they had developed a species-specific radioimmunoassay for brown trout vitellogenin.

Interference, perhaps due to a protein effect, was observed with serum dilutions at less than $1: 80$. This was found also with male brown trout serum as well as that of rams. Thus, sera for assay were routinely diluted at least 100-fold and the limit of detection for VTG in trout plasma was $5 \mu \mathrm{g} \mathrm{ml}^{-1}$.

\section{FINNOCK CHARACTERISTICS}

The rhythms for upstream migration and sizes of finnock in the Calonne were similar to those reported by Richard (1986). The predominance of the $2+$ age class in Richard's spawning finnock $(88.6 \%)$ is confirmed here for the females $(6 \%$ of $1+, 93 \%$ of $2+,<1 \%$ of $3+$ ). Seasonal changes in the GSI of gametogenic trout sampled at the Pont L'Evêque trap were similar to those described by Billard (1987) in brown trout from a Welsh farm.

The levels of 11-KT and E2 reported here correspond with those noted by Le Bail et al. (1983), in domestic brown trout in July and August and by Norberg et al. (1989) in Baltic wild female sea trout, 90 days before ovulation. Conversely, the levels of maturational gonadotropin appear elevated with respect to those oberved by Crim \& Idler (1978) and Breton et al. (1983) in domestic females at the beginning of the comparable accelerated oocyte growing phase.

Levels of VTG recorded in vitellogenic females were of the same order as those observed by Norberg et al. (1989) in Baltic sea trout. Further, Idler et al. (1979) considered that wild female Atlantic salmon, captured in a river, with VTG value in excess of $0.396 \mathrm{mg} \mathrm{ml}^{-1}$ (which is similar to our observations: $0.45 \mathrm{mg} \mathrm{ml}^{-1}$ in the sample), will spawn in the year of capture. It should be noted that this level corresponds to the minimum detection threshold for the immunological method of Le Bail \& Breton (1981). This technique, adapted to field conditions (Le Bail et al., 1981) could thus have been used in the finnock study, as $0.30 \mathrm{mg} \mathrm{ml}^{-1}$ is the threshold that we considered as the minimum for females undergoing vitellogenesis.

Generally, the proportion of gametogenic individuals among migrating finnock was similar to that observed in brown trout of the same age in the Massif Armoricain (Maisse \& Baglinière, 1990). It is, however, necessary to distinguish two periods: summer, when $33 \%$ of $1+$ and $87 \%$ of $2+$ were gametogenic, and autumn, when all individuals were. These two periods are distinct as very few fish migrated in September, as found by Richard (1986). If the autumn migration is reproductive, that in summer, including immature individuals, appears to be of another order. The majority of summer finnock carried sea lice or were scarred, while autumn finnock were unscathed. This parasite cannot live for long in fresh water (Wootten et al., 1982) so the summer finnock had moved up the river 
recently, whereas the autumn finnock had probably spent some time in the river before reaching the trap at Pont L'Evêque.

In agreement with Richard (1986), who observed that the greatest number of fish ran upstream during neap tide when the mixing of coastal waters with those from the cooler open sea was at a minimum, we suggest that the summer run is induced by a rise in temperature of the sea close to the estuary. This increase in temperature has two consequences: firstly, a decrease in the quantity of dissolved oxygen (for

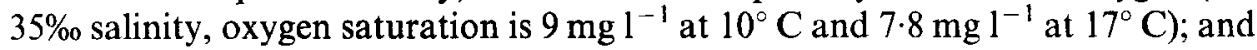
secondly, a probable increase in oxygen consumption by the trout, as shown by Madan Mohan Rao (1971) in the rainbow trout. The sum of these factors could lead to discomfort in trout in the estuary, aggravated by sea lice parasitism, which is activated by an increase in temperature. Returning to less saline and better oxygenated waters $\left(9 \cdot 7 \mathrm{mg}^{-1}\right.$ at $17^{\circ} \mathrm{C}$, the summer temperature of the Calonne) would be physiologically advantageous to the trout, and would rid them of lice.

Following this hypothesis, finnock and older sea trout might be distinguished by the different behaviour of downstream migrant juveniles. Those which stay near to the coast and estuaries which heat-up considerably in summer, might produce finnock, while others which reach the cooler summer waters of the open seas, might not return to the river except to reproduce as older sea trout. Such a hypothesis needs to be tested, and would require study of the extent to which the degree of smolting (i.e. salinity tolerance) influenced the time spent in the estuary.

The research was supported in part by a contract with the Conseil Supérieur de la Pêche. We thank G. Leclerc for trapping and sampling.

\section{References}

Benzecri, J. P. (1973). L'Analyse des Données. Tome 2: L'Analyse des Correspondances. Paris: Dunod.

Billard, R. (1987). The reproductive cycle of male and female brown trout (Salmo trutta fario): a quantitative study. Reproduction, Nutrition, Dévelopement 27, 29-44.

Breton, B., Prunet, P. \& Reinaud, P. (1978). Sexual differences in Salmon gonadotropin. Annales de Biologie Animale, Biochimie, Biophysique 18, 759-765.

Breton, B., Fostier, A., Zohar, Y., Le Bail, P. Y. \& Billard, R. (1983). Gonadotropine glycoprotéique maturante et oestradiole-17 $\beta$ pendant le cycle reproducteur chez la truite fario (Salmo trutta) femelle. General and Comparative Endocrinology 49, 220-231.

Crim, L. W. \& Idler D. R. (1978). Plasma gonadotropin, estradiol, and vitellogenin and gonad phosvitin levels in relation to the seasonal reproductive cycles of female brown trout. Annales de Biologie Animale, Biochimie, Biophysique 18, 1001-1005.

Fahy, E. (1978). Variation in some biological characteristics of British sea trout, Salmo trutta L. Journal of Fish Biology 13, 123-138.

Fostier, A., Weil, C., Terqui, M., Breton, B. \& Jalabert B. (1978). Plasma estradiol-17 $\beta$ and gonadotropin during ovulation in rainbow trout (Salmo gairdneri R.). Annales de Biologie Animale, Biochimie, Biophysique 18, 929-936.

Fournel, F. \& Euzenat, G. (1979). Etude sur "les Salmonidés migrateurs du bassin de l'Arques (Seine-Maritime)". 1 partie. Bulletin d'Information du Conseil Supérieur de la Pêche 114, 25-49.

Idler, D. R., Hwang, S. J., Crim, L. W. \& Reddin, D. (1981). Determination of sexual maturation stages of Atlantic salmon (Salmo salar) captured at sea. Canadian Journal of Fisheries and Aquatic Sciences 38, 405-413.

Kawauchi, H., Suzuki, K., Itoh, H., Swanson, P., Naito, N., Nagahama, Y., Nozaki, M., Nakai, Y. \& Itoh, S. (1989). The duality of teleost gonadotropins. Fish Physiology and Biochemistry 7, 29-38. 
Le Bail, P. Y. \& Breton, B. (1981). Rapid determination of the sex of puberal salmonid fish by a technique of immunoagglutination. Aquaculture 22, 367-375.

Le Bail, P. Y. \& Fostier, A. (1984). Techniques d'identification du sexe et d'estimation de la maturité sexuelle chez les poissons vivants. In L'Aquaculture du Bar et des Sparidés (Barnabé, G. \& Billard, R., ed.), pp. 45-52. Paris: INRA.

Le Bail, P. Y., Maisse, G. \& Breton, B. (1981). Détection des femelles de salmonidés en vitellogenèse. 1 Description de la méthode et mise en oeuvre pratique. Bulletin Français de Pisciculture 283, 79-88.

Le Bail, P. Y., Fostier, A. \& Marcuzzi, O. (1983). Limites et améliorations du sexage des salmonidés par dosage de la 11-cétotestostérone circulante. Canadian Journal of Zoology 61, 457-460.

Le Cren, E. D. (1985). The Biology of Sea Trout. Summary of a Symposium held at Plas Menai, 24-26 October 1984. Pitlochry: Atlantic Salmon Trust.

Madan Mohan Rao, G. (1971). Influence of activity and salinity on the weight-dependent oxygen consumption of the rainbow trout Salmo gairdneri. Marine Biology 8, 205212.

Maisse, G. \& Baglinière J. L. (1990). The biology of brown trout, Salmo trutta L., in the River Scorff, Brittany: a synthesis of studies from 1973 to 1984. Aquaculture and Fisheries Management 21, 95-106.

Norberg, B. \& Hauss, C. (1988). An homologous radioimmunoassay for brown trout (Salmo trutta) vitellogenin. Fish Physiology and Biochemistry 5, 59-68.

Norberg, B., Björnsson, B. T., Brown, C. L., Wichardt, U.-P., Deftos, L. J. \& Haux, C. (1989). Changes in plasma vitellogenin, sex steroids, calcitonin, and thyroid hormones related to sexual maturation in female brown trout (Salmo trutta). General and Comparative Endocrinology 75, 316-326.

Pratten, D. J. \& Shearer, W. M. (1983). Sea trout of the North Esk. Fisheries Management 14, 49-65.

Richard, A. (1982). La truite de mer (Salmo trutta) en Basse-Normandie; premières observations. Colloque sur la production et la commercialisation du poisson d'eau douce. Association International Entretiens Ecologiques.

Richard, A. (1986). Recherches sur la truite de mer, Salmo trutta L., en Basse-Normandie. Thèse $3 \mathrm{e}$ cycle, Ecologie, Université de Rennes I.

Richard, A., Baglinière, J. L. (1990). Description et interprétation des écailles de truite de mer, Salmo trutta L., de deux rivières de Basse-Normandie, l'Orne et la Touques. Bulletin Français de la Pêche et de la Pisciculture 319, $239-257$.

Tyler, C. R. \& Sumpter, J. P. (1990). The purification and partial characterization of carp, Cyprinus carpio, vitellogenin. Fish Physiology and Biochemistry 8, 111-120.

Went, A. E. J. (1962). Irish sea trout, a review of investigations to date. Scientific Proceedings A, Royal Dublin Society 1, 265-296.

Wootten, R., Smith, J. W. \& Needham, E. A. (1982). Aspects of the biology of the parasitic copepods Lepeophtheirus salmonis and Caligus elongatus on farmed salmonids, and their treatment. Proceedings of the Royal Society, Edinburgh 81B, 185-197. 